\title{
The Indigofera trita complex (Fabaceae: Indigofereae) in Australia
}

\author{
Peter G. Wilson and Ross Rowe
}

\begin{abstract}
Wilson, Peter G. and Rowe, Ross (National Herbarium of New South Wales, Royal Botanic Gardens, Mrs Macquaries Road, Sydney, NSW, Australia 2000) 1994. The Indigofera trita complex (Fabaceae: Indigofereae) in Australia. Telopea 5(4):637-645. Usage of the name Indigofera trita in Australia is reviewed. The major morphological variants in Australia are compared with the taxonomic concepts adopted by various overseas workers and it is concluded that the variation observed cannot be accommodated within any of the hierarchies of infraspecific taxa recognised in this complex by those workers. Furthermore, the three taxa that can be recognised are here considered to warrant specific rank under the names I. trita L., I. ewartiana Domin and I. polygaloides M. Scott.
\end{abstract}

\section{Introduction}

Indigofera trita sens. lat. is a pantropical complex that has perplexed taxonomists for many years and all attempts to resolve it in a way that is widely accepted have failed.

Early this century it was usual to accept three separate species in this group, 1 . trita L.f., I. subulata Vahl ex Poir. and I. scabra Roth. Meikle (1950) had experienced much difficulty in separating the African I. subulata with three leaflets from the more or less pantropical I. scabra with five or more leaflets, and reduced the latter to a variety of the former; he considered that the name I. trita had been applied wrongly to African plants, with the possible exception of four specimens. Gillett (1958) agreed in general with Meikle's conclusions but recognised five varieties of which one, var. maffeii, embraced Meikle's doubtful specimens. In each of these treatments, the emphasis was on the variation that occurs among African populations.

Ali (1958), working in Pakistan, approached the complex from a statistical point of view with a 'Chi square' analysis of the variation in three characters: length of inflorescence axis, leaflet number and fruit orientation. His results showed that the variation in the character states was not normally distributed and he concluded that a single species, I. trita, should be recognised with two subspecies (subsp. trita and subsp. subulata) based on fruit orientation; within each of these he recognised two varieties (var. trita + var. maffeii, and var. subulata + var. scabra). However, in this three-character analysis each variety was separated from the others by only one character, and Ali's argument for the recognition of two subspecies was based largely on the geography of the taxa (Ali 1958: 557). This may be the reason why later authors did not accept his two-tiered scheme and only adopted the varieties.

Gillett (1971) followed Ali in accepting four varieties, but made no reference to the subspecies, and Thulin (1983) followed Gillett's treatment of the complex in his enumeration of Ethiopian Indigofera species.

De Kort \& Thijsse (1984), in their study of the genus in Malesia, produced yet another arrangement of these taxa. They recognised only three infraspecific taxa in I. trita, all 
at subspecific rank, viz., subsp. trita, subsp. scabra and subsp. subulata, relegating var. maffeii to the synonymy of subsp. subulata.

Sanjappa (1984) made a study of the Indian members of this complex using the same approach and characters as Ali. He concluded that five varieties should be recognised for India, var. trita, var. maffeii, var. scabra, var. marginulata (from a specific name long placed in synonymy) and var. purandharensis (newly described). Sanjappa, also, did not adopt Ali's subspecies.

Isely (1982) described a new variety under the illegitimate name $I$. mucronata for a member of this complex in Florida, without any mention of I. trita. McVaugh (1987) accepted, also without mention of $I$. trita, the name $I$. jamaicensis for members of this complex in Mexico; both these names were listed as synonyms of I. trita subsp. scabra by de Kort \& Thijsse (1984). Kartesz \& Gandhi (1990), on the other hand, accept that the New World material is correctly placed in I. trita and recognise Isely's variety in Florida; they did not clearly state their opinion on the applicability or otherwise of the epithet scabra to American material.

It is clear from this survey of the literature that there is a great deal of variation in the treatment of this complex in other parts of the world. This complex is currently under review by a number of workers (Schrire, pers. comm.) and it is to be hoped that a consensus view will emerge that is consistent with taxonomic concepts applied elsewhere in the genus.

Most publications by overseas workers (e.g. Ali 1958, Gillett 1971, Sanjappa 1984 and de Kort \& Thijsse 1984) list 'Australia' as part of the distribution of $I$. trita var./subsp. trita. Only Gillett (1958) remarked on any variability amongst Australian specimens assigned to this taxon.

\section{I. trita complex in Australia}

Mueller (1862: 103-104) recorded I. trita for Australia but his concept included specimens with a range of inflorescence lengths (about $1.5-15 \mathrm{~cm}$ ) at odds with contemporary concepts of the species. Bentham (1864: 197) also noted a range of inflorescence lengths and stated 'the racemes sometimes short, dense, and nearly sessile, sometimes pedunculate, interrupted, and attaining several inches'; he noted, too, that the leaves were on rare occasions 5-foliolate. Gillett (1958: 101) also remarked that some Australian specimens of $I$. trita were atypical in having more than three leaflets and longer inflorescences.

A number of workers have attempted to deal with this variation. Bailey (1914: 74) described a specimen with five leaflets and inflorescences exceeding the leaves, which he had received from Hughenden, under the name I. subulata. Hacker (1990: 188) treated specimens with this combination of features as $I$. trita var. maffeii. Domin (1926) described a plant from Hughenden with these features as a new species, I. ewartiana. Such plants differ from typical var. subulata in having spreading fruits and from typical var. maffeii in having a longer staminal tube, and from both of these in having larger, pink (rather than red) flowers and larger fruits, and frequently being 5 -foliolate.

Scott (1915) described a Northern Territory plant with slender, more or less decumbent stems, trifoliolate leaves, long inflorescences and slender, spreading fruits as I. polygaloides, and Domin (1926) described a similar plant from Rockhampton as I. amaliae. These plants differ primarily from all named variants of $I$. trita in having a thickened, perennating tap-root, pink flowers and a rather narrow fruit. 


\section{Distribution of Characters}

As indicated in the discussion above, most workers have concentrated on variation in three characters, viz. inflorescence length, leaflet number and angle of fruit relative to the inflorescence axis. In the present study other characters were also found to be informative, viz. habit, flower colour, flower size and fruit size; fruit angle was of limited value in the analysis of the Australian populations. An examination of the available herbarium material in the light of these characters led to the conclusion that three taxa could be recognised. Further, we conclude that the practice of subsuming all variation to varietal or subspecific rank under a single species, I. trita, is unworkable with regard to the Australian populations. Such a ranking would be at odds with the treatment of similar variability elsewhere in the genus. We consider that the extent of morphological and, to some extent, ecological differentiation between them and the apparent lack of intergradation is indicative of taxa of specific rank. The three taxa accepted here are I. trita, I. ewartiana and I. polygaloides.

\section{Key to species}

1 Inflorescences usually to $40 \mathrm{~mm}$ long, mostly shorter than the leaf, peduncle mostly $<4 \mathrm{~mm}$ long; flowers red or orange-red; fruit $20-30 \mathrm{~mm}$ long, 2-3 mm diam.

1. I. trita

$1^{*}$ Inflorescences usually $40-150 \mathrm{~mm}$ long, Ionger than the leaf, peduncle $\geq 4 \mathrm{~mm}$ long; flowers pink to purple; fruit $\geq 30 \mathrm{~mm}$ long, or $<2 \mathrm{~mm}$ diam.

2 Plant annual, \pm erect; flowers $6-8 \mathrm{~mm}$ long; fruit $30-50 \mathrm{~mm}$ long, $2.5-3 \mathrm{~mm}$ diam.; leaflets 3-5(-7), 10-35 mm long; inflorescence mostly $60-150 \mathrm{~mm}$ long

2. I. ewartiana

2* Plant a perennial herb, often prostrate; flowers 4-5.5 long; fruit 20-30 mm long, 1-1.8 mm diam.; leaflets 3, 5-25 mm long; inflorescence mostly 40-120 mm long

3. I. polygaloides

\section{Indigofera trita L.f.}

(Linnaeus 1782: 335)

TYPE: 'Habitat in India'; holo LINN 923.3, photo NSW.

I. timorensis DC. (Candolle 1825: 223). Type: '? in ins. Timor'; holo G-DC n.v., NSW microfiche.

Erect, annual or short-lived perennial herb, mostly $0.15-0.45 \mathrm{~m}$ high, with taproot; young stems ridged, green to grey, strigose; hairs moderately dense to dense, hyaline or white, appressed, equally biramous; older stems green to grey, hairs moderately dense. Leaves trifoliolate, (8-)20-35(-47) mm long; petiole (1.5-)4-10(-15) mm long; rachis furrowed, multicellular hairs between leaflet pairs absent or sparse and inconspicuous, orange, pointed-linear; stipellae absent. Leaflets elliptical to obovate; lateral leaflets (5-)8-17(-22) mm long, (2.0-)3.5-7(-10) mm wide, terminal leaflet (5-)10-20 $(-25) \mathrm{mm}$ long, $2.5-7(-10) \mathrm{mm}$ wide; upper surface green to grey, hairs moderately dense (rarely sparse), appressed or spreading; lower surface green to grey, hairs moderately dense (rarely sparse), appressed; apex obtuse and shortly mucronate. Stipules linear, or narrow and triangular, (1.0-)1.5-3 $\mathrm{mm}$ long, pubescent, not persistent. Inflorescence (5-)10-35(-50) $\mathrm{mm}$ long, shorter to longer than the leaf; peduncle 
0.5-3(-5.0) $\mathrm{mm}$ long; bracts narrow-ovate, $0.5-1.5 \mathrm{~mm}$ long; pedicel $0.5-1 \mathrm{~mm}$ long. Calyx 2.5-5 mm long; hairs moderately dense, grey, appressed; lobes longer to much longer than the tube, subequal, $1.5-4 \mathrm{~mm}$ long. Corolla dull or pale red, sometimes orange-red; standard elliptical to obovate, 5-6 mm high, $3.5-4.5 \mathrm{~mm}$ wide, hairs moderately dense, hyaline, apex obtuse and mucronate; wing narrow-obovate to spathulate, 5-6 mm long, 1.5-2.3 mm wide; keel 5-5.7 mm long, 1.5-2 mm deep, hairs along the bottom sparse, hyaline or white, apex rounded, lateral pockets present, 0.5$0.9 \mathrm{~mm}$ long. Staminal tube colourless, $3-4 \mathrm{~mm}$ long. Ovary sparsely to moderately hairy; stigma capitate. Pod spreading to descending, 4-angled, mostly $20-30 \mathrm{~mm}$ long, 2-3 mm diam., yellowish to pale brown, strigose, hairs moderately dense, appressed, apex shortly beaked or pointed, endocarp not spotted. Seeds variable, spherical to elongated-cuboid, mostly 8-10 per fruit, $1.5-2.5 \mathrm{~mm}$ long, $1-1.5 \mathrm{~mm}$ wide.

DistRIBUTION AND habiTAT: Australia (Western Australia, Northern Territory, Queensland - see Figure 1), Indonesia, Burma, Pakistan, India and Sri Lanka. Found in a wide range of habitats: cracking clay, rich loamy or sandy soils on open plains or amongst rocks of various types on hills.

NoTES: Citation of the specimen LINN 923.3 as holotype follows Gillett (1958) who considered that this was the only specimen which it was certain had been seen by the younger Linnaeus; this position requires re-evaluation (Schrire, pers. comm.).

A much fuller synonymy is given in de Kort \& Thijsse (1984) under subsp. trita. In the present study, special attention was paid only to the type of $I$. timorensis; this name, based on a specimen originating from close to Australia, seemed to be the only synonym likely to be applicable to one of the other taxa recognised herein.

The description above is based primarily on specimens from the Pilbara region of Western Australia, since published descriptions seem to indicate that the populations there match the typical form of $I$. trita most closely. These populations may most readily be distinguished from others in Australia by the hairs on the upper surface of the leaflets being appressed and with equally long arms, a character highlighted by de Kort \& Thijsse (1984). The following specimens are representative of these populations.

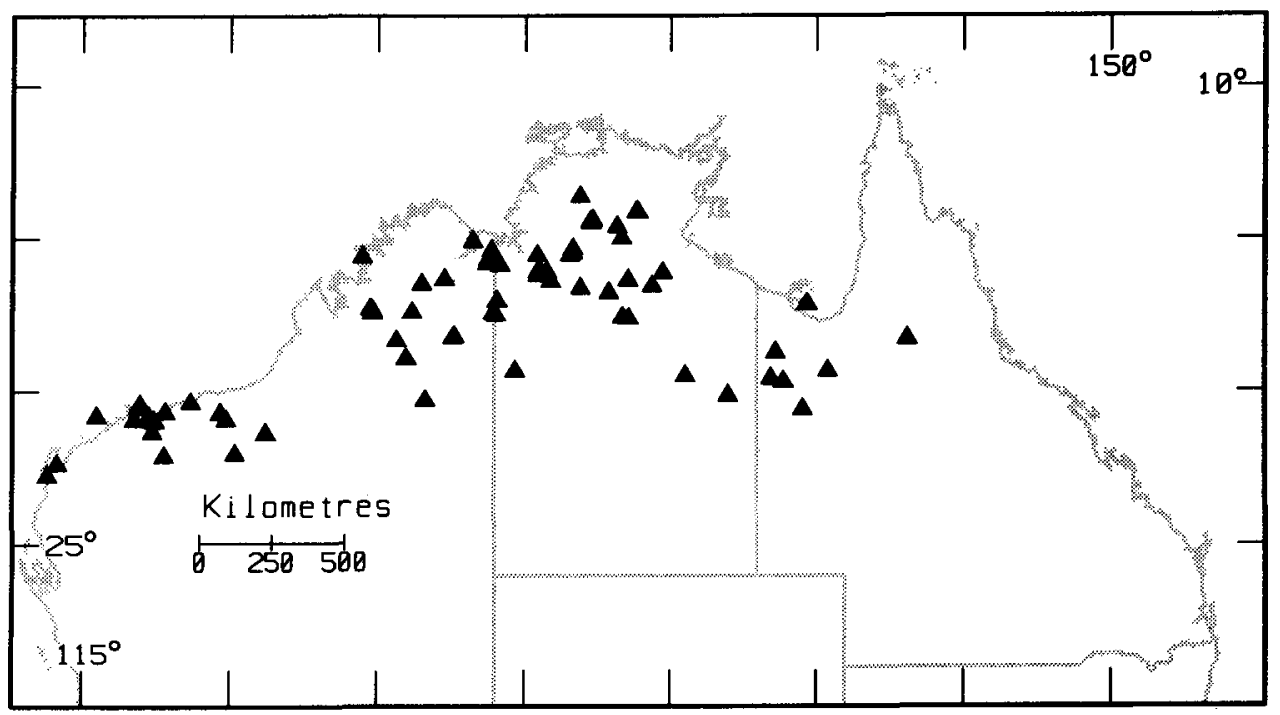

Figure 1. Distribution of Indigofera trita in Australia. 
Selected specimens: Western Australia: Fortescue: Legendre Island, Dampier Archipelago, Royce 7259, 9 June 1962 (PERTH); Tanguin Hill, Gregory Range, c. 130 km SE Shay Gap, Newbey 10470, 13 July 1984 (CANB). Carnarvon: $23.9 \mathrm{~km}$ from Exmouth road on Ningaloo road, Wilson 1120 \& Rowe, 15 Sep 1991 (NSW, PERTH).

The other Australian populations have the hairs on the upper leaflet surface with unequally long arms but also show a significant amount of other morphological variability. Some of this variability may be worthy of recognition at infraspecific rank but such decisions would be dependent on the availability of a broader range of such variant specimens and a more satisfactory resolution of the taxonomy of $I$. trita sens. lat. on a world-wide basis. None of these variants matches any of the infraspecific taxa recognised by workers in other countries. The variation observed amongst herbarium specimens of $I$. trita includes: plant to $1 \mathrm{~m}$ high (Thomson 942, Gregory National Park); plant with small leaves with very conspicuously spreading hairs (Dunlop 5818, Keep River); plants with similar leaves to Dunlop 5818 but multistemmed and semi-prostrate (Hartley 14460, Weaber Range; Wilson 226, Napier Range on limestone); plant with inflorescence to $5 \mathrm{~cm}$ long (Mitchell 2291, Slate Is.); plant with short fruits, 10-14 mm long (Dunlop 4184, near Katherine on limestone); and plant with a few 5-foliolate leaves (Russell-Smith 6630, Roper River). The following specimens are representative of the remaining Australian populations:

SeleCted SPECIMENS: WeSTERn Australia: Gardner: southern slopes of Weaber Range, Hartley 14460, 11 Mar 1978 (CANB); Slate Islands, Mitchell 2291, 5 Apr 1992 (NSW, PERTH). Fitzgerald: Karunjie Station, Ritson 9, Feb 1959 (CANB); Moola Bulla, Gardner 10174, 10 May 1951 (PERTH). Dampier: Lennard River, just E of crossing on Gibb River road, Wilson 207, 9 May 1988 (NSW, L, PERTH); SW side of Napier Range, Wilson 226 \& Jacobs, 12 May 1988 (NSW, L, PERTH). Hall: Christmas Creek, Gardner 9862, 24 Jan 1951 (PERTH). Canning: head of Breaden Valley, Southesk Tableland, George 15496, 29 Apr 1979 (PERTH, DNA). NORTHERN TERritorY: Darwin \& Gulf: $11 \mathrm{~km}$ NW of Katherine, Dunlop 4184, 3 Apr 1977 (DNA, CANB); 4 miles [c. 6.4 km] W Mountain Valley H/S, Nelson 243, 10 Apr 1962 (CANB, DNA, MEL, NSW). Victoria River: Keep River, Dunlop 5818, 28 Feb 1981 (DNA, CANB); Pondun Waterhole, Muranji Stock Route, Maconochie 2301, 10 Jan 1978 (CANB, DNA). Barkly Tableland: 4 miles [c. $6.4 \mathrm{~km}$ ] ESE of Frewena, Perry 661, 29 Apr 1948 (CANB). QuEENSLAND: Burke: 6 miles [c. $9.6 \mathrm{~km}$ ] E of Undilla Station, Perry 1065, 28 May 1948 (BRI, CANB). Cook: Forest Home, Gilbert River, White 1340, 10 Feb 1922 (BRI).

\section{Indigofera ewartiana Domin}

(Domin 1926: 189)

TYPE: QueEnsLand: 'Gebüsch und Grasflächen der Rolling Downs am Fusse des Mt. Walker bei Hughenden (Domin II.1910)'; holo PR 527207.

Erect to spreading, short-lived perennial herb to subshrub, 0.1-0.5(-0.9) $\mathrm{m}$ high, with woody rootstock; young stems ridged, grey to green or yellowish, strigose; hairs moderately dense to dense, hyaline to green or golden, appressed, equally biramous; older stems grey to green, hairs sparse to moderately dense. Leaves trifoliolate or 35(-7)-foliolate, (12-)25-50(-55) mm long; petiole 4-15 mm long; rachis furrowed, multicellular hairs between leaflet pairs absent, or sparse, inconspicuous, orange (very pale, hyaline to yellowish), club-shaped to pointed-linear; stipellae absent, or inconspicuous, $0.2-1 \mathrm{~mm}$ long. Leaflets ovate to elliptical or narrow-elliptical; lateral leaflets (5-)10-30(-38) mm long, (4-)6-12(-16) mm wide, opposite, terminal leaflet (8)15-35(-40) mm long, (4-)5-15(-17) mm wide; upper surface grey to green, hairs sparse to moderately dense, appressed (rarely spreading); lower surface grey to green, hairs moderately dense, appressed (rarely spreading); apex acute, or obtuse and mucronate. Stipules narrow-triangular to subulate, 2-6 mm long, pubescent, not persistent. Inflorescence (30-)60-150(-240) mm long, longer than leaf; peduncle 4-15(-20) $\mathrm{mm}$ long; bracts narrow-triangular, $1-2 \mathrm{~mm}$ long; pedicel $0.5-1.5 \mathrm{~mm}$ long. Calyx 
(1.3-)2-4(-5.5) mm long; hairs sparse to moderately dense, grey or greenish, appressed; lobes longer than the length of the tube (rarely much longer than the tube), subequal to equal, (0.5-)1-2(-3.0) mm long. Corolla pink to purple; standard obovate to elliptical, (5.5-)6.5-8(-9.0) $\mathrm{mm}$ high, (3.5-)4.5-6(-8.0) $\mathrm{mm}$ wide, hairs sparse to moderately dense, hyaline, or white, apex obtuse (occasionally mucronate); wing narrow obovate to spathulate, (5.0-)6-8(-9.5) $\mathrm{mm}$ long, (1.8-)2.5-3.5 mm wide; keel 5-7.5 mm long, 1.5-2.5 mm deep, hairs along the bottom sparse, hyaline, or white, margin ciliate, apex acute and beaked, lateral pockets present, $0.5-1.2 \mathrm{~mm}$ long. Staminal tube colourless, $3.5-4 \mathrm{~mm}$ long. Ovary sparsely hairy to moderately hairy; stigma capitate. Pod spreading to descending, 4-angled, (10-)30-50 mm long, 2.5-3 mm diam., brown, strigose, hairs sparse to moderately dense, appressed, apex pointed to shortly beaked, endocarp not spotted. Seeds oval to cylindrical, mostly $8-10(-14)$ per fruit, 1.5-2.8(-3.2) $\mathrm{mm}$ long, 1-1.8 $\mathrm{mm}$ wide.

Distribution AND HABITAT: Queensland, Northern Territory, and South Australia (Figure 2). Found almost exclusively on heavy loam soils, cracking clays and black soil plains, particularly in grasslands.

NotEs: Domin considered that this species was related to I. parviflora (now Indigastrum parviflorum, see Schrire 1992) but this was due to the larger number of leaflets and the lack of fruit on his specimens. Indigastrum parviflorum differs from this species in having shorter inflorescences, non-angular pods, glabrous corolla and rostrate keel. Indigofera ewartiana differs from $I$. trita most conspicuously in having larger, pink (rather than red) flowers and larger fruits. These two species are also ecologically distinct with $I$. ewartiana virtually restricted to heavy soils.

Selected specimens: Northern Territory: Darwin \& Gulf: approx. 20 miles [c. $32 \mathrm{~km}$ ] N Daly Waters, Byrnes 1350, 4 Feb 1969 (DNA). Barkly Tableland: 15 miles [c. 24 km] E of Brunchilly, Chippendale 7088, 17 June 1960 (AD, BRI, CANB, NSW). Central North: 13 miles [c. $20.8 \mathrm{~km}$ ] SSE Soudan, Nicholls 875, 15 June 1968 (BRI, CANB, DNA). SOutH Australia: Lake Eyre: 29 miles [c. $47 \mathrm{~km}$ ] from Cadelga outstation on Cordillo Downs track, Lothian 609 \& Francis, 29 Aug 1960 (AD). QuEENSLAND: Burke: $67 \mathrm{~km} \mathrm{WNW}$ of Mt Isa, $6 \mathrm{~km} \mathrm{~N}$ of Mingera Creek, Harris 288, 15 Apr 1989 (BRI, NSW). Gregory North: Breadalbane, N of Bedourie, Blake 12342, 23 July 1936 (CANB). Gregory South: Retreat, about 50 miles [c. 80 km] SW of Yaraka, Heaton s.n., Apr 1957 (BRI).

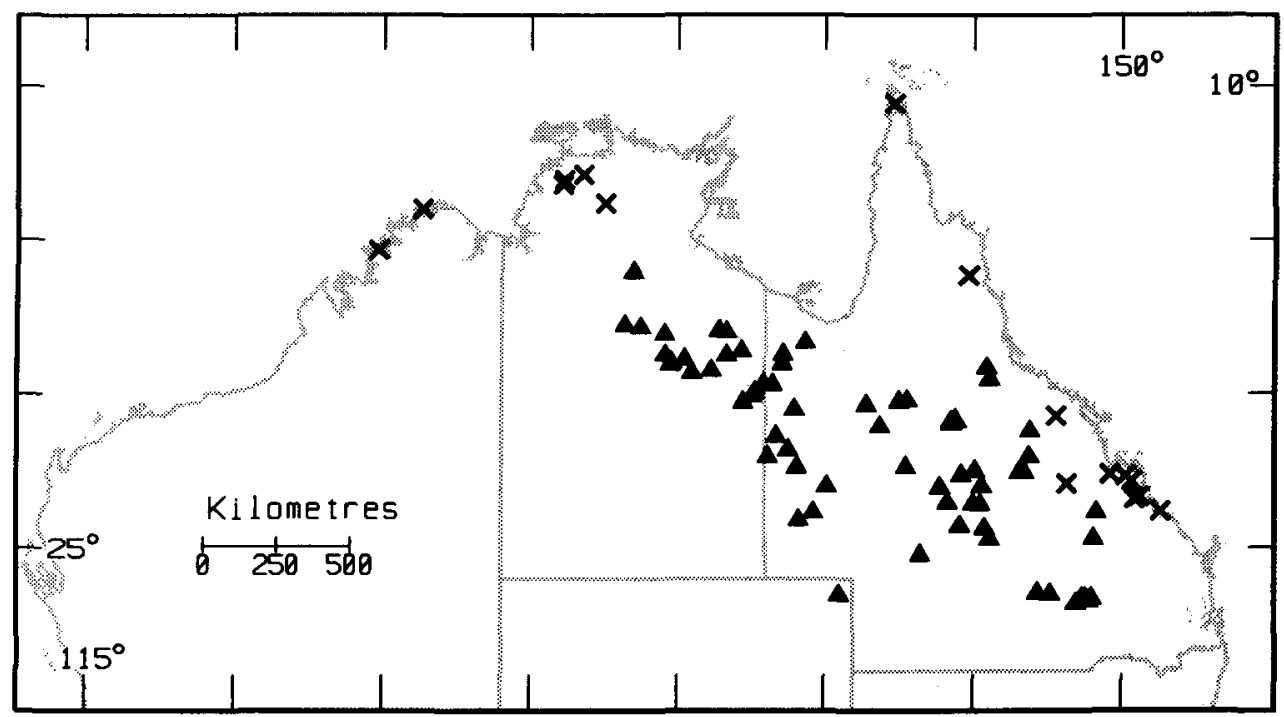

Figure 2. Distribution of Indigofera ewartiana $(\boldsymbol{\Lambda})$ and Indigofera polygaloides (x). 
Mitchell: Mineeda, 7 miles [c. $11.2 \mathrm{~km}$ ] E of Blackall, Everist 1988, 14 Feb 1940 (BRI). Warrego: Morven, Blake 5649, 5651, 1 May 1934 (BRI). South Kennedy: Elgin Downs, Bisset s.n., 7 Nov 1964 (BRI). Maranoa: 8 miles [c. 12.8 km] E of Roma, Jones 1941, 19 Apr 1961 (BRI, MEL).

\section{Indigofera polygaloides $M$. Scott}

(Scott 1915: 88) non Gagnepain (1916: 198)

Type: Northern Territory: Pine Creek, C.E.F. Allen 85, Feb 1914 (holo K, ?iso NSW)

I. amaliae Domin (1926: 188). Type: Queensland: [Rockhampton], Amalie Dietrich 1854, [Feb 1866]; lecto PR 527202 (here designated); isolecto PR 527203, HBG, CANB 282834, MEL.

Prostrate or suberect perennial herb, $0.1-0.3 \mathrm{~m}$ high, with a thickened taproot; young stems ridged, green, strigose; hairs moderately dense, hyaline to white, appressed, equally biramous; older stems green, glabrescent to hairs sparse. Leaves trifoliolate, (12-)5-35(-48) $\mathrm{mm}$ long; petiole 3-13 $\mathrm{mm}$ long; rachis furrowed, multicellular hairs between leaflet pairs absent; stipellae absent or inconspicuous and $0.3-1 \mathrm{~mm}$ long. Leaflets elliptical to obovate; lateral leaflets $5-15(-20) \mathrm{mm}$ long, 3-8(-12) $\mathrm{mm}$ wide, opposite, terminal leaflet 5.5-24 mm long, 3-10(-14) mm wide; upper surface green, hairs unequally biramous, sparse to moderately dense, shortly spreading to spreading; lower surface green (paler than above), hairs equally biramous, sparse to moderately dense, appressed; apex obtuse and apiculate. Stipules narrow and triangular, or linear, (1-)2-4 mm long, sparsely pubescent, semi-persistent. Inflorescence (15-)40$120(-360) \mathrm{mm}$ long, longer than leaf; peduncle 5-20(-39) $\mathrm{mm}$ long; bracts triangular, $0.5-2 \mathrm{~mm}$ long; pedicel $0.5-1 \mathrm{~mm}$ long. Calyx (2.0-)2.5-4 mm long; hairs moderately dense, white, appressed; lobes longer than the length of the tube, subequal to equal, (1.2-)1.5-3 mm long. Corolla pink to purple; standard obovate, $4-5 \mathrm{~mm}$ high, $3.2-4.7$ $\mathrm{mm}$ wide, hairs sparse to moderately dense, hyaline to white, apex obtuse; wing narrow obovate to spathulate, $4-5.5 \mathrm{~mm}$ long, $1.3-2 \mathrm{~mm}$ wide; keel $4.5-5 \mathrm{~mm}$ long, 1.2-2 $\mathrm{mm}$ deep, hairs along the bottom sparse, hyaline to white, margin ciliate, apex rounded, lateral pockets present, $0.5-1.2 \mathrm{~mm}$ long. Staminal tube colourless, 3-4 $\mathrm{mm}$ long. Ovary glabrous to sparsely hairy; stigma capitate. Pod ascending to descending, four-angled, (10-)20-30 mm long, $1.5 \mathrm{~mm}$ diam., brown, strigose to glabrescent, hairs sparse to moderately dense, appressed, apex acute (sometimes kinked upwards), endocarp not spotted. Seeds cuboid 7-10 per fruit, 1.5-2 mm long, $1 \mathrm{~mm}$ wide.

Distribution and habrTat: Queensland, Northern Territory, and Western Australia (Figure 2). Occurs on stony slopes or plains and generally sandy soils in open woodland or sometimes in cleared areas.

Notes: The specimen of Allen 85 at NSW is a very good match for the type specimen at Kew and could be a piece of the same plant. However, the two labels, both in the collector's own hand, show different localities; 'Pine Creek' on the Kew sheet and 'Bachelor [sic] Farm' on the sheet at NSW. Pine Creek is about $125 \mathrm{~km}$ due south-east of Batchelor.

This species is represented by relatively few specimens and hence it is difficult to assess the significance of the variation that is apparent between the types of I. amaliae and I. polygaloides, and across the geographic range. At present we are treating all specimens as belonging to a single taxon.

Scott distinguished this species from I. trita mainly on the basis of its slender habit and very long racemes. This species also differs from $I$. trita, and all its named varieties, in having a thickened tap-root, pink flowers and a very narrow fruit. Geographically, it appears to be restricted to a fairly narrow coastal or subcoastal strip. 
The lectotype of I. amaliae and its duplicate at PR lack specific collecting details, as do the other specimens originating from HBG; only the duplicate at MEL, which Mueller probably received directly from Amalie Dietrich, has these details.

Selected specimens: Western Australia: Gardner: behind Paspaley pontoon in Port George, Mitchell 2328 \& Willing, 6 Apr 1992 (NSW, PERTH); Water Supply Creek, Freshwater Bay, Mitchell 2874, 23 Mar 1993 (NSW, PERTH). NORTHERN TERRITORY: Darwin \& Gulf: 4 miles [c. 6.4 km] SW Stapleton Railway Siding, Muspratt 104, 4 Mar 1963 (DNA, MEL, NSW); 40 miles [c. 64 km] E Pine Creek, Byrnes 1342, 29 Jan 1969 (DNA); 2 km E of Bark Hut, Cowie 1377 \& Booth, 8 Feb 1991 (NSW). QueENSLAND: Cook: Horn Island, Clarkson 6477, 10 Apr 1986 (BRI, MBA, NSW); $10 \mathrm{~km}$ south of the Palmer River crossing on the Peninsula Development road, Clarkson 6667 \& McDonald, 4 Mar 1987 (BRI, MBA, NSW, QRS). Port Curtis: 'Nullegar', about 2 km west of house, Anderson 854, 19 Apr 1979 (BRI); 'The Springs', $20 \mathrm{~km} \mathrm{~N}$ of Glen Geddes, Anderson 2944, 2 Mar 1982 (BRI); Neerkool [Neerkol] Creek, Bowman 127, - (MEL). North Kennedy: Bowen River, unknown coll., - (MEL). Leichhardt: Peak Downs, Mueller s.n., - (MEL, NSW).

\section{Acknowledgements}

We wish to thank the heads of the herbaria cited for loans of herbarium material. We are grateful to Andrew A. Mitchell for collecting specimens for us and for his hospitality and assistance in the field; our thanks also to Brian Schrire for valuable discussion on the variation within the $I$. trita complex in other parts of the world. This study was supported by a grant from the Australian Biological Resources Study.

\section{References}

Ali, S.I. (1958) Revision of the genus Indigofera L. from W. Pakistan and N.W. Himalayas. Bot. Notis. 3: 543-577.

Bailey, F.M. (1914) Contributions to the Flora of Queensland and British New Guinea. Queensland Agric. J. ser. 2, 2: 73-78.

Bentham, G. (1864) Indigofera. Pp. 194-201 in Flora Australiensis, vol 2.

Candolle, A.P. de (1825) Indigofera. Pp. 221-233 in Prodromus systematis naturalis regni vegetabilis, vol 2.

Domin, K. (1926) Indigofera. Biblioth. Bot. 89 (3): 741-746.

Gagnepain, F. (1915-16) Papilionacées nouvelles ou critiques. Not. Syst. 3 (6-7): 180-206.

Gillett, J.B. (1958) Indigofera (Microcharis) in tropical Africa with the related genera Cyamopsis and Rhynchotropis. Kew Bull., Additional Series 1.

Gillett J.B. (1971) Indigofereae. In E. Milne-Redhead \& R.M. Polhill, Flora of Tropical East Africa, Leguminosae 3, Papilionoideae: 321-328.

Hacker J.B. (1990) A Guide to Herbaceous and Shrub Legumes of Queensland. (University of Queensland Press).

Isely, D. (1982) New combinations and one new variety among the genera Indigofera, Robinia, and Tephrosia (Leguminosae). Brittonia 34: 339-341.

Kartesz, J.T. \& Gandhi, K.N. (1990) Nomenclatural notes for the North American Flora. II. Phytologia 68: 421-427.

de Kort, I. \& Thijsse, G. (1984) A revision of the genus Indigofera (Leguminosae-Papilionoideae) in southeast Asia. Blumea 30: 89-151.

Linnaeus, C. von, filius (1782) Supplementum Plantarum.

McVaugh, R. (1987) Indigofera. Pp. 536-551 in Flora Novo-galiciana, vol. 5.

Meikle, R.D. (1950) Tropical African plants: XXI, Leguminosae, Indigofera \& Dolichos. Kew Bull. 1950: 351-354.

Mueller, F. (1862) Fragmenta Phyt. Austr. vol. 3.

Sanjappa, M. (1984) Indigofera trita L.f. (Fabaceae - Papilionoideae) complex in India. Bull. Bot. Surv. India 26: 114-119.

Schrire, B.D. (1992) New combinations and resurrected names in Microcharis and Indigastrum (Fabaceae-Papilionoideae). Bothalia 22: 165-170. 
Scott, M.B. (1915) 832. Indigofera polygaloides. Kew Bull. 1915: 88-89.

Thulin (1983) Leguminosae of Ethiopia. Opera Botanica 68: 82-100.

Manuscript received 18 August 1993

Manuscript accepted 24 November 1993 